\title{
Tom McArthur's English Today
}

\author{
KINGSLEY BOLTON, DAVID GRADDOL, and \\ RAJEND MESTHRIE
}

\author{
As English Today notches up a century, it's high time to \\ acknowledge Tom McArthur's inimitable contribution to the \\ study of English worldwide.
}

\section{Introduction}

Tom McArthur's contribution to English language studies has been immense, and has had a powerful impact at a number of levels. Tom started his life as an educator, gaining crucial exposure to English across the globe very early in his career, when in one of his first jobs teaching English at the Cathedral School in Bombay (Mumbai). After a varied academic career, which included a post at the University of Quebec, Tom returned to the UK to start a new journal for Cambridge University Press, English Today. Tom's brief at that time was to be the founding editor of a journal that would inform a wide readership about the highways and byways of the English language, during an era when English was becoming a global language at an unprecedented speed.

\section{The early days}

Tom took on the task of editorship with enthusiasm and flair, and very shortly after the journal first appeared in January 1985, it built up a wide readership among all kinds of people: broadcasters, educationalists, language teachers, journalists, as well as many others in the academic world. At a time when universities had yet to experience the managerial corporatisation which characterises many colleges and universities today, Tom attracted some of the biggest names - and biggest minds - in English linguistics to write for the journal. Early issues in the first five years included such luminaries as Jean Aitchison, Richard W. Bailey, Dwight Bolinger, W. F. Bolton, Robert Burchfield, David Crystal, Sidney Greenbaum,
Manfred Görlach, Braj B. Kachru, Robert Le Page, Alan Maley, Frank Palmer, John Sinclair, Peter Strevens, Peter Trudgill, and Randolph Quirk. Articles varied from commentaries on English worldwide to issues of usage, points of grammar, and lexicography, to the description of dialects of English within the UK, matters of language planning and language policies, to the discussion of literatures in English. English Today, from the outset, was characterised by diversity and an immediacy which reflected the changing roles of English as it developed increasingly large numbers of users across the globe. Tom thereby established a tradition of diversity and topicality that the present editors of the journal have striven to live up to.

Over the years, Tom's work on English Today has not been confined to mere editorial matters, but as regular readers know, he has also played a major authorial role, contributing scores of articles to the journal himself over the years. These began with 'An ABC of World English', which ran from ET2 to ET4 (April - October 1985) and included some sixty-odd articles and notes and queries, up to his latest piece on 'Teaching and using English in Hong Kong, China and the world'.

\section{Tom's scholarship}

Tom McArthur's scholarship is not only expressed in the articles he authored for English Today, but also in a collection of published books on English language studies, so substantial as to form a small library of work (as the bibliography at the end of this article demonstrates). Early in his publishing career, Tom's interests in the English language included such topics as 
English for academic purposes, English grammar, pronunciation, sentence structure, and English vocabulary. In fact, the study of words has fascinated him throughout his career. He has compiled and edited two dictionaries of English, the Dictionary of English Phrasal Verbs and their Idioms (Collins, 1974), and the Longman Lexicon of Contemporary English (1981), and he has also published widely on lexicography, with such

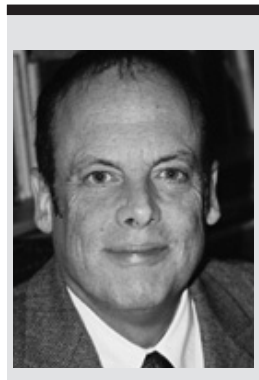

KINGSLEY BOLTON is Chair Professor of English Linguistics at City University, Hong Kong. He has published widely on sociolinguistics and world Englishes. Publications include 'Chinese Englishes: A Sociolinguistic History' (2003, Cambridge University Press), 'World Englishes: Critical Concepts in Linguistics' (2006, Routledge, with Braj B. Kachru), and 'Asian Englishes' (2007, Routledge, with Braj B. Kachru). He is also the founding editor of the Hong Kong University Press book series, 'Asian Englishes Today'

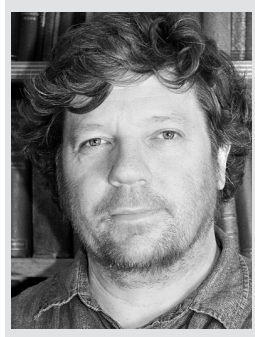

DAVID GRADDOL is an independent researcher and publisher who has published widely on English linguistics and global English, and lectures on such topics worldwide. His publications include 'English: History, Diversity and Change' (with Dick Leith and Joan Swann, Routledge 1996), 'The Future of English?' (1997, The English Company/ The British Council), 'English in a Changing World' (with Ulrica Meinhof, AILA, 1999), and 'English Next' (2006, The English Company/The British Council).

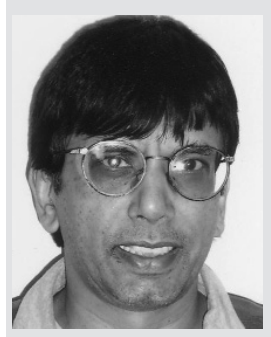

RAJEND MESTHRIE is Professor of Linguistics in the Department of English at the University of Cape Town, with research interests in sociolinguistics, and language contact and variation in South Africa. His publications include 'English in Language Shift: The History, Structure and Sociolinguistics of South African Indian English' (Cambridge University Press, 1992), 'Language in South Africa' (ed., Cambridge University Press, 2002), and 'Introducing Sociolinguistics' (Edinburgh University Press, 2000). books as Worlds of Reference: Lexicography, Learning and Language from the Clay Tablet to the Computer (Cambridge, 1986), Living Words: Language, Lexicography and the Knowledge Revolution (University of Exeter Press, 1998), and Lexicography in Asia (Password Publishers, 1998). Very recently, Tom and his wife, Jacqueline Kam-mei Lam-McArthur have just completed a three-way dictionary of English, Putonghua and Cantonese, which will be published later this year.

Another area where Tom has published, which is less well known, is that dealing with Eastern religions, an interest that has found expression in a number of writings, including three books, Understanding Yoga: A Thematic Companion to Yoga and Indian Philosophy, and Yoga and the Bhagavad-Gita: An Introduction to the Philosophy of Yoga (both published by Aquarian, 1986), as well as Unitive Thinking (Aquarian, 1988). At the core of much of his other writing, of course, there has always been a strong interest in varieties of English, and Englishes worldwide. He was a co-author of Languages of Scotland (1979, with A. J. Aitken), completed a monograph on English in Quebec (1989), and has published a number of other works surveying English around the world. These include Models of English (1992, Cambridge University Press), The English Languages (1998, Cambridge), and The Oxford Guide to World English (2003, Oxford University Press). For many, however, the crowning achievement of Tom's scholarship was the monumental Oxford Companion to English Language (1992), which achieved recognition as a work of outstanding scholarship, and has earned Tom a well-deserved place in the pantheon of major scholars in the field of English studies.

\section{The Oxford Companion to the English Language}

The Companion, with its 1184 pages, was a weighty volume in more ways than one. Its Associate Editors were such distinguished English linguists as John Algeo, Robert E. Allen, Richard W. Bailey, W. F. Bolton, Raymond Chapman, Sidney Greenbaum, Braj B. Kachru, Suzanne Romaine, Loreto Todd and Christopher Upward. Its contributors included the Associate Editors, together with a list of scholars that represented English language and linguistics from across the globe, with Jean Aitchison (then in London), A. J. Aitken (Edinburgh, UK), Laurie J. Bauer (Wellington, New Zealand), John Baugh 


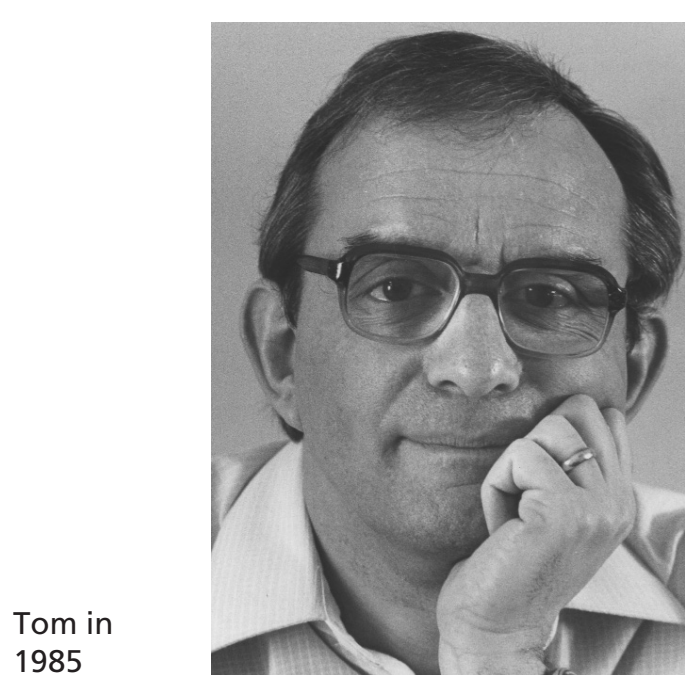

(Stanford, USA), David Blair (Sydney, Australia), Eyamba G. Bokamba (Illinois, USA), Jean and William Branford (Rhodes University, South Africa), Christopher J. Brumfit (Southampton, UK), Frederic G. Cassidy (Wisconsin-Madison, USA), Paul Christophersen (Ulster, UK), Isagani R. Cruz (Manila, the Philippines), David Crystal (Bangor, UK), Wimal Dissanayake (Honolulu, USA), John Edwards (Nova Scotia, Canada), Andrew Gonzales (Manila, the Philippines), Yamuna Kachru (Illinois, USA), Gerald Knowles (Lancaster, UK), Peter H. Lowenberg (San Jose, USA), Michael McCarthy (Nottingham, UK), J. Derrick McClure (Aberdeen, UK), Rajend Mesthrie (Cape Town, South Africa), Salikoko Mufwene (Chicago, USA), Cecil L. Nelson (Indiana, USA), Frank R. Palmer (Reading, UK), John Platt (Monash, Australia), William S. Ramson (Canberra, Australia), Larry E. Smith (Honolulu, USA), S. N. Sridhar (New York, USA), James Stanlaw (New York, USA), Peter Strevens (Cambridge, UK), Mary Tay (Singapore), Peter Trudgill (Essex, UK), and Katie Wales (London, UK).

The Companion drew much praise throughout the English-speaking world. In the US, The New York Times praised its 'genial and witty writers', while the Library Journal judged it 'a superb survey'. In Britain, The Guardian deemed it an 'essential' and 'rare' reference work. The Times noted that 'Tom McArthur has succeeded magnificently' in editing the volume, which was 'comprehensive yet focused', and an 'excellent guide to the history, geography and contours of English'. The Times' glowing review concluded that, 'Earning its shelf-space beside the Oxford Companion to
Literature, this book gives us English at large at last.' The Companion became a book club choice on both sides of the Atlantic, and attracted a general reading public as well as an interested audience among a generation of English linguists and their students.

Some seventeen years on, the Companion has yet to be surpassed as the most authoritative reference work on English studies worldwide (although Tom's own Oxford Guide to World English, 2003, did update some of the information on English in particular localities). The work has stood the test of time not least because of its comprehensiveness and detail. The entries dealing with 'English' (and its compounds) as head words, for example, run to 22 pages, and include the following:

\section{ENGLISH, ENGLISH ACADEMY, ENGLISH AS A FOREIGN LANGUAGE, ENGLISH AS AN INTERNATIONAL LANGUAGE, ENGLISH AS A SECOND DIALECT, ENGLISH AS A SECOND LANGUAGE, ENGLISH ASSOCIATION, ENGLISH CANADA, ENGLISH CANADIAN, ENGLISH DIALECT DICTIONARY, ENGLISH DIALECT SOCIETY, ENGLISH ENGLISH, ENGLISHES, ENGLISH FIRST, ENGLISH FOR ACADEMIC PURPOSES, ENGLISH FOR CIVIL AVIATION, ENGLISH FOR GENERAL PURPOSES, ENGLISH FOR MARITIME COMMUNICATION, ENGLISH FOR OCCUPATIONAL PURPOSES, ENGLISH FOR SPECIFIC/SPECIAL PURPOSES, ENGLISH IN ENGLAND, ENGLISHISM, ENGLISHIZE, ENGLISH LANGUAGE AMENDMENT, ENGLISH LANGUAGE EXAMINATIONS, ENGLISH LANGUAGES, ENGLISH LANGUAGE SCHOOL, ENGLISH LANGUAGE TEACHING, ENGLISH LITERATURE, ENGLISHMAN/ WOMAN, ENGLISH-ONLY MOVEMENT, ENGLISH PALE, ENGLISH PLACE-NAMES, ENGLISH PLUS, ENGLISH PRONUNCIATION DICTIONARY, ENGLISHRY, ENGLISH-SPEAKING UNION, ENGLISH STUDIES, ENGLISH TEACHING, ENGLISH TEACHING FORUM, ENGLISH TODAY, ENGLISH WORLD-WIDE, ENGLISHY, ENG LIT. (The Oxford Companion, pp. 352-75)}

The scope of the work (as the entries for 'English' demonstrate) was widely comprehensive and encyclopedic. As explained in a front section, the Companion accommodated a total of 17 major 'themes' or 'topic areas', including biography, education, geography, grammar, history, language, literature, style, media, names, reference, speech, technology, usage, varieties, words, and writing. In addition to these, there were also five regional sub-themes related to geography, i.e. Africa, Americas, Asia, Europe, and Oceania (including Australasia). 
In many instances, the scaffolding of a classical education and a command of rhetoric shows through, as in the entries (cryptically bylined as T. McA.) for ALLEgory, ANAPAEST, BINOMIAL, DEIXIS, DIALECTIC, ECHOLALIA, ETYMON, GLOSSOLALIA, HAMARTIA, HEPTARCHY, HOMEOTELEUTON, LOCUTION, LOGIC, MIMESIS, ORTHOEPY, PARALIP SIS, PERIPHRASIS, PHONAESTHESIA, RHOTACISM, SUPPLETION, SYNCOPE, etc. In other sections, a fondness, or at least a strong interest in, certain geographical locations comes through in the authoring or selection of multiple entries for Scots, Scotland, and things Scottish, as well as the substantial subset of entries dealing with India and South Asia. Nor is the canonical coverage of the history of English neglected, with multiple entries dealing with ANGLO-SAXON, ANGLO-SAXON CHRONICLE, BEOWULF, GERMANIC LANGUAGES, HISTORY OF ENGLISH, MIDDLE ENGLISH, NORMAN FRENCH, OLD ENGLISH, SCANDINAVIAN LANGUAGES, etc.

Yet another layer is provided by the selection of people, including language scholars, literary figures, politicians, and statesmen, all of whom are included, one surmises, because Tom has judged that they have contributed in some major way to the development of English or English studies in its widest sense. Thus we have entries (to name but a selection) for such diverse figures as David Abercrombie, Aelfric of Eynsham, Louis Alexander, Jane Austen, Matthew Arnold, The Brontë Sisters, John Bunyan, Robert Burchfield, Robert Burns, Thomas Carlyle, Lewis Carroll, William Caxton, Geoffrey Chaucer, Noam Chomsky, Winston Churchill, William Cobbett, Samuel Taylor Coleridge, Arthur Delbridge, John Dryden, Emily Dickinson, T. S. Eliot, Henry Fielding, Henry W. Fowler, Mohandas Karamchand Gandhi, Theodor Seuss Geisel (Dr. Seuss), Michael A. K. Halliday, Thomas Hardy, Otto Jespersen, Samuel Johnson, Ben Jonson, Daniel Jones, William Jones, James Joyce, Rudyard Kipling, Hans Kurath, F. R. Leavis, D. H. Lawrence, Marshall McLuhan, Herman Melville, H. L. Mencken, V. S. Naipaul, Jawaharlal Nehru, Ngugi Wa Thong'o, Charles Talbut Onions, George Orwell, Eric Partridge, Isaac Pitman, Randoph Quirk, I. A. Richards, Peter Mark Roget, Edward Sapir, William Shakespeare, Walter Skeat, Peter Strevens, Richard Chenevix Trench, Mark Twain, Laurence Urdang, Wilhelm Viëtor, Noah Webster, W. D. Whitney, Benjamin Whorf, Oscar Wilde, Virginia Woolf, William Wordsworth, as well as a slew of lesser-known figures, very often lexicographers, for whom Tom appears to have had a particular fondness.

Yet, despite the scope and voluminous depth of the Companion a good helping of wit also emerges, not least through the selection of items. Thus, one entry is devoted to BLURB, a term, we are informed, which was coined by one Frank Gelett Burgess who created a comic-book cover, 'embellished by a sexy young woman whom he called Miss Belinda Blurb'. Many of the shorter entries are informative little gems that add to our knowledge of the high roads and backlanes of English and English studies, as in the concise entries for such items (to name but a few) as ABUSE, ADAGE, AMPERSAND, BOMBAST, CANT, CARTOON, DIATRIBE, DUB, ELOCUTION, EURASIAN, FABER, FAUX AMI, GODZONE, GRAFFITI, HINDUSTANI, HIRI MOTU, IMAGINATION, INCUNABLE, JANUS WORD, JOHN BULL, KIWI, KOINE, LEXICON, LINGO, MACRON, MESTIZO, NEWSPEAK, NICENELLYISM, OATH, ORATURE, PASTICHE, PATOIS, QWERTY, ROUGH, RUNE, SABIR, SCROLL, TEXT, THESIS, UNCIAL, UTTERANCE, VERBALISM, VULGAR, and WORD GAME. In connection with this last item, it is worth noting that Tom even sees fit to give the BBC TV programme, 'Call my Bluff', its own entry. This was a popular TV programme from 1965 until 2005, where celebrity guests had to compete in conjuring up definitions of obscure words from the Oxford English Dictionary. Its inclusion in the Companion, one infers, is a reflection of Tom's own liking for wordplay, as well as this particular programme.

\section{From WH Smith to electronic databases}

The encyclopedic frame of reference that characterised the Companion has also found expression in English Today. In English Today 91-2, the journal published an index for the years 1985-2007, which clearly shows the wideranging comprehensiveness of ET over the previous twenty-two years. The eighteen themes identified comprise: World English; Africa; the Americas (the United States, Canada, the Caribbean, and Latin America); Asia (East Asia, South Asia, South East Asia, and West Asia); Australasia (Australia, New Zealand, PapuaNew Guinea and the Pacific islands); Europe (offshore, mainland); history; grammar; usage (including the Fairman debate); usage (including gender and political correctness); style, register, rhetoric, and journalism; plain language, 
jargon, and gobbledygook; words, names, signs, neologisms, and etymology; lexicography, works of reference, and publishing (including the $O E D$ ); speech and pronunciation; writing, spelling, and punctuation; language, linguistics, language teaching, and education (including ELT, TEFL, TESL, TEIL); literature, literary theory, poetry, translation, the media, and editing; and communication, technology, computing, and corpora.

The journal has not stood still in its interests, but has evolved over the years, mirroring and reporting on new developments in the remarkable story of the global spread of English in recent decades. It has also changed format over the years. Veteran readers of the journal will recall that in its early life the journal had a glossy magazine format very similar to the popular History Today magazine. Tom has recounted for us the story of his recruitment, which, as we recall, went something like this (no doubt losing something in the retelling): While teaching at university in Quebec, Tom was enrolled to edit this exciting new publication by the then Head of ELT publications at Cambridge University Press. He left Quebec and returned to England, setting up house in Cambridge. Two years or so later, however, the organizational winds at CUP changed, and the journal (which had even been sold at WH Smith's) abruptly changed format, as its home changed to the journals section of Cambridge University Press. There, ever since, the journal has remained, as a unique testament, one might argue, to the inspirational editorship of Tom, who took with him many of ET's loyal early readers, who have stayed with the journal ever since.

Over the years, as academic journals have been forced to adopt a standardized business and production model, one imagines that English Today must have tested the understanding of its publishers, given its rather unorthodox character and personality. While other academic journals have taken on the strait-jacket of the standard peer review process, which often involves a two year wait before research reports see publication, ET has remained cockily independent, immediate and fresh with its mixture of comment, debate, reportage, as well as research. And it has also maintained a high readership, not at its very earliest levels perhaps, but nevertheless significantly higher than the vast majority of journals in the field (both in its print and electronic forms).

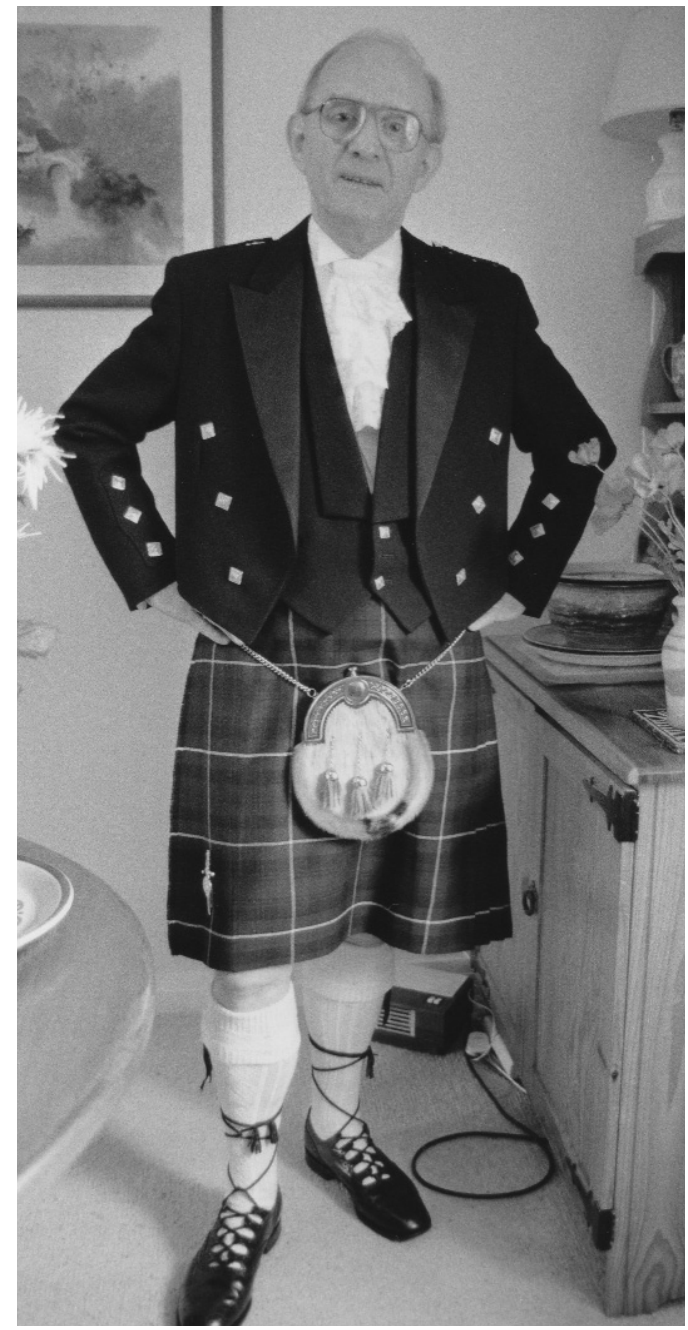

Tom resplendent in tartan.

The subject matter of English Today has also varied over the years, with the focus tending to move from the British Isles in early issues, towards the distant parts of Europe and Asia more recently. Indeed, in the last few years, one remarkable feature has been the increasing frequency of submissions dealing with the issues of English in China and 'China English'. Another recent innovation has been the emergence of debates of English in Europe, and the emergence of English as a Lingua Franca (ELF) as an area for research and debate. In all this, English Today has kept pace with the changing face of English studies, and, in particular, research and publishing on English worldwide.

All this has required an immense effort from its Founding Editor, and one can think of few others in the academic world who could have 
handled such a task with such flair and enthusiasm. At the beginning, ET attracted articles from established scholars in the field, and a number of these have continued to publish in the journal up to the present, but, from the early 1990s onwards a recurring feature of ET was that it gave increasing space to younger academics who were just getting their feet wet in the world of academic publishing. One now a very well established Full Professor of English - remarked a few years ago, 'I'll always be grateful to Tom, because he published my very first academic article in English Today.' This comment could have come from successive generations of younger scholars over the years, whom Tom has encouraged to write up their research results, or to put down their thoughts or their experiences on paper, and to send them to him. Tom has always been extremely generous in his encouragement and support for the interesting and the innovative as well as for fresh young authorial talent, and this generosity has showed through the journal at every stage of its development. Simply told, English Today, for many of its readers, has been less a journal and more an institution.

When Tom stepped down as Editor last year, it was a mark of his contribution, that he was replaced not simply by one new editor, but by the three of us. When that happened, we were unanimous in our conviction, that whatever the future might hold, we would do our very best to maintain the spirit of English Today, and to strive that the journal remain as topical and fresh, as jargon-free, as lively, and as innovative as the English Today that we've appreciated, enjoyed, and respected over the past twenty-five years. We trust that the future issues of the journal will live up to the tradition and heritage that has been handed to us. Samuel Johnson's famous entry on 'lexicographer' glossed the word as 'a writer of dictionaries; a harmless drudge, that busies himself in tracing the original, and detailing the signification of words'. One can think of many words to describe Tom's contribution, but drudge is not one of them. In fact, Tom has been a lexicographer, but he has also been a grammarian, a teacher, a major scholar in the field of English studies, as well as a mentor and inspiration for a whole generation of scholars. The bibliography that follows gives some indication, we believe, of the breadth of
Tom McArthur's interest and the considerable energy that he has devoted to scholarship in the field.

\section{A bibliography of books written and edited by Tom McArthur}

McArthur, T.. 1972a. Building English Words. London: Collins.

-. 1972b. Patterns of English. London: Collins.

-. 1972c. A Rapid Course in English for Students of Economics. London: Oxford University Press.

—. 1972d. Using English Prefixes and Suffixes. London: Collins.

—. 1973a. Using Compound Words. London: Collins.

—. 1973b. Using Phrasal Verbs. London: Collins.

— \& Atkins, B. 1974. Dictionary of English Phrasal Verbs and their Idioms. London: Collins.

— \& Heliel, M. 1974. Learning Rhythm and Stress. London: Collins.

— \& Hughes, J. 1974. Times, Tenses and Conditions. London: Collins.

— \& Wakely, R. 1974. Using Modal Verbs. London: Collins.

— \& Aitken, A. J. (eds.) 1979. Languages of Scotland. Edinburgh: W. and R. Chambers.

- 1981. Longman Lexicon of Contemporary English. Harlow: Longman

—. 1983. A Foundation Course for Language Teachers. Cambridge: University Press.

- 1984. The Written Word: A Course in Controlled Composition. Oxford: University Press.

—. 1986a. Understanding Yoga: A Thematic Companion to Yoga and Indian Philosophy. Wellingborough: Aquarian.

-. 1986b. Worlds of Reference: Lexicography, Learning and Language from the Clay Tablet to the Computer. Cambridge: University Press.

—. 1986c. Yoga and the Bhagavad-Gita: An Introduction to the Philosophy of Yoga. Wellingborough: Aquarian.

—. 1988. Unitive Thinking. Wellingborough: Aquarian,

-. 1989. The English Language as Used in Quebec: A Survey. Kingston, Ont.: Strathy Language Unit, Queens University.

— \& Waddell, Peter. 1990. Vision Warrior: The Hidden Achievement of John Logie Baird. Kirkwall: Orkney.

-. (ed.) 1992. The Oxford Companion to the English Language. Oxford: University Press.

- 1996. The Concise Oxford Companion to the English Language. Oxford: University Press.

—. 1998a. Lexicography in Asia. Jerusalem: Password Publishers.

—. 1998b. The English Languages. Cambridge : University Press.

—. 1998c. Living Words: Language, Lexicography and the Knowledge Revolution. Exeter: University of Exeter Press.

—. 2003. The Oxford Guide to World English. Oxford: University Press. 